\title{
Pengaruh Motivasi Internal dan Eksternal terhadap Diabetes Self Management di Wilayah Kecamatan Gombong Kabupaten Kebumen
}

\author{
Ernawati $^{1}$, Elsa Pudji Setiawati², Titis Kurniawan ${ }^{3}$ \\ ${ }^{1}$ Magister Keperawatan Fakultas Keperawatan Universitas Padjadjaran \\ ${ }^{2}$ Departemen Ilmu Kesehatan Masyarakat Fakultas Kedokteran Universitas Padjadjaran \\ ${ }^{3}$ Fakultas Keperawatan Universitas Padjadjaran
}

\begin{abstract}
Abstrak
Diabetes Melitus merupakan penyakit kronik, oleh karena itu peran self-management sangat penting dalam perawatan maupun pencegahan komplikasi. Salah satu faktor yang mempengaruhi diabetes self management yaitu motivasi. Tujuan menganalisis dimensi kebutuhan dan keyakinan yang menggambarkan motivasi internal, menganalisis dimensi penghargaan dan harga diri yang menggambarkan motivasi eksternal, menganalisis dimensi diet, aktivitas fisik, pemeriksaan rutin, konsumsi obat, perawatan kaki yang menggambarkan diabetes self management, menganalisis pengaruh motivasi internal dan eksternal terhadap diabetes self management. Penelitian kuantitatif korelasional,dilaksanakan 12 Februari s.d 6 Juni 2015 di Kecamatan Gombong, Kabupaten Kebumen, sampel 92 responden, teknik proporsional sampling, pendekatan cross sectional. Menggunakan kuesioner karakteristik demografi, Treatment Self-Regulation Questionnaire (TSRQ), The Summary of Diabetes Self Care Activities (SDSCA). Analisis data menggunakan Structural Equation Modeling (SEM) dengan software Smart-PLS.Hasil menunjukkan dimensi kebutuhan $(0,989)$, keyakinan $(0,989)$ mampu menggambarkan motivasi internal, dimensi penghargaan $(0,925)$, harga diri $(0,800)$ mampu menggambarkan motivasi eksternal. Dimensi diet, aktivitas fisik, pemeriksaan rutin, konsumsi obat, perawatan kaki mampu menggambarkan diabetes selfmanagement.
\end{abstract}

Kata Kunci : Diabetes mellitus tipe 2, diabetes self management, motivasi eksternal, motivasi internal

\section{The Effect of Intenal and External Motivation to Diabetes Self Management in Gombong Subdistrict Kebumen Regency}

\author{
Abstract
}

Diabetes Mellitus is one of the serious health problems in Indonesia. Since DMis a chronic disease, patients 'role (selfmanagement) is very important either for treatment or DM-related complications prevention. One of the factors that influence diabetes self-management is motivation. To analyze the dimensions of the needs and beliefs as the reflector of internal motivational, self-esteem and reward dimensions as the reflector of external motivational, diet, physical activities, routine medical checkup, medicine consumption, and foot care reflecting diabetes self-management, and also to analyze the strength of effect of both internal and external motivation on diabetes self-management. This correlational quantitative, locations in Gombong subdistric, Kebumen regency, on 12 February to 6 June 2015, research involved 92 responden taken by proportional sampling technique. Data were collected by using questionnaire of demographic characteristic, Treatment Self-Regulation Questionnaire (TSRQ), and The Summary of Diabetes Self Care Activities (SDSCA). Data were analyzed by multivariable Structural Equation Modeling (SEM) analysis using software Smart-PLS.This results showed that the need (loading factor $=0,989)$ and belief dimensions $(0,989)$ were able to reflect internal motivation, rewards and esteem dimension able to describe external motivation. Diet, physical activities, routine medical checkup, medicine consumption, and foot care dimensions were able to reflect variables with good diabetes self-management.

Keywords: Diabetes self-management, internal and external motivation, type II diabetes mellitus

Korespondensi :

Ernawati

Magister Keperawatan Fakultas Keperawatan Universitas Padjadjaran

Jl. Raya Bandung Sumedang KM 21 Jatinangor, Sumedang.

Mobile : 081392115059

Email : erna.azzaam@gmail.com 


\section{Pendahuluan}

Diabetes mellitus adalah suatu penyakit kronis yang menimbulkan gangguan multisistem dengan karakteristik hiperglikemia yang disebabkan kerja insulin yang tidak adekuat (Smeltzer et al, 2009). Diabetes mellitus merupakan salah satu penyakit kronis yang cukup banyak diderita oleh penduduk dunia. Peningkatan jumlah penderita diabetes akan terjadi di negara berkembang termasuk Indonesia disebabkan pertumbuhan populasi, penuaan, diet yang tidak sehat, obesitas dan kurangnya aktivitas fisik (WHO, 2014). Menurut Federasi Diabetes Internasional terjadi kenaikan jumlah penderita DM tipe 2 pada kasus tahun 2012 sejumlah 371 juta, pada tahun 2035 diperkirakan jumlah kasus akan meningkat 55\% menjadi 592 juta penderita. Prevalensi DM di Indonesia meningkat 2-3 kali dibandingkan dengan negara maju, sehingga DM merupakan masalah kesehatan yang serius (PERKENI, 2011).

Mengingat jumlah penderita DM yang terus meningkat dan besarnya biaya perawatan akibat komplikasi, maka upaya yang paling baik adalah dengan melakukan pencegahan (Suyono, 2006). Upaya pencegahan untuk meminimalkan terjadinya komplikasi pada penderita diabetes dilakukan dengan penerapan self-management. Menurut L.Greca et al (2005) aktivitas perawatan diri (self care) pada pasien DM dapat mencegah morbiditas dan kematian. Perilaku self management dapat dilakukan dengan peningkatan pengetahuan dan kemampuan yang cukup untuk melakukan pengontrolan terhadap penyakit, pengelolaan gejala, pengobatan, konsekuensi fisik, psikososial dan perubahan gaya hidup yang melekat pada penderita DM (Weiler \& Janice, 2007).

Self management dipengaruhi oleh motivasi (Wu et .al, 2006), health belief, self efficacy, dukungan sosial (Gao, et.al, 2013; Ariani, 2011) dan pengetahuan (Kose \& Gurkan, 2008). Penelitian terkait faktor pengetahuan, self efficacy, health belief dan dukungan sosial telah membuktikan pengaruh terhadap diabetes self management sehingga faktor tersebut tidak diteliti. Beberapa penelitian juga membuktikan bahwa motivasi mempengaruhi diabetes self management, namun pada penelitian sebelumnya tidak menjelaskan secara lengkap tentang motivasi internal dan eksternal, dimensi pembentuk motivasi menggambarkan motivasi internal dan eksternal. Oleh karena itu, penting untuk dilakukannya penelitian tentang pengaruh motivasi internal dengan dimensi pembentuknya yaitu keyakinan dan kebutuhan. Motivasi eksternal dengan dimensi pembentuknya yaitu harga diri dan penghargaan serta melihat seberapa besar pengaruh motivasi internal dan eksternal terhadap. diabetes self management.

\section{Metode}

Penelitian ini menggunakan metode kuantitatif, dengan pendekatan cross sectional, yaitu variabel independen dan variabel depanden diukur dalam satu waktu.. penelitian ini dilaksanakan di 14 desa di wilayah Kecamatan Gombong pada tanggal 12 Februari s.d 6 Juni 2015. Populasinya semua penderita DM tipe 2 yang berdomisilidi Kecamatan Gombong. Metode pengambilan sampel dengan probability sampling dengan teknik proposional random sampling pada 14 wilayah berjumlah 92 responden. Kriteria inklusi yaitu penderita DM tipe 2 dan mampu berkomunikasi dengan baik secara lisan maupun tulisan, sedangkan kriteria ekslusi sampel adalah penderita DM tipe 2 yang tidak bersedia menjadi responden.

Variabel independen pada penelitian ini adalah motivasi internal dan motivasi eksternal. Motivasi internal direfleksikan oleh dua reflektor yaitu dimensi kebutuhan dan dimensi keyakinan. Motivasi eksternal direfleksikan oleh dua reflektor yaitu dimensi penghargaan dan dimensi harga diri. Sedangkan variabel dependennya adalah diabetes self management yang direfleksikan oleh lima reflektor yaitu dimensi diet, pemeriksaan rutin, aktivitas fisik, konsumsi obat dan perawatan kaki.

Peneliti menggunakan tiga jenis kuesioner yaitu kuesioner tentang karakteristik demografi, motivasi dan diabetes self management pada penderita DM tipe 2. Kuesioner karakteristik responden terdiri dari umur, jenis kelamin, tingkat pendidikan, pekerjaan, status sosial ekonomi/penghasilan perbulan, dan lama menderita DM. Kuesioner tentang motivasi internal dan eksternal yang diadopsi dari Treatment Self-Regulation Questionnaire (TSRQ) yang telah diterjemahkan dalam bahasa Indonesia. Kuesioner untuk mengukur diabetes self management menggunakan The Summary of Diabetes Self Care Activities (SDSCA).

Peneliti melakukan uji validitas dan reliabilitas instrumen motivasi kepada 24 penderita DM tipe 2. Pengumpulan data dilakukan oleh peneliti dengan terlebih dahulu menentukan responden yang memenuhi kriteria inklusi. Peneliti memberikan kebebasan (autonomy) kepada calon responden terkait keikutsertaan dalam penelitian. Peneliti melakukan kunjungan rumah dan menjelaskan maksud tujuan, tata cara penelitian, manfaat, kerahasiaan data yang diberikan serta menanyakan kesediaan menjadi responden. Responden diminta mengisi ketiga kesioner 
yaitu kuesioner demografi, motivasi internal dan eksternal dan diabetes self management dengan didampingi oleh peneliti yang bertugas menjelaskan maksud dari pertanyaan dalam kuesioner. Peneliti memeriksa kelengkapan jawaban yang telah diisi. Teknik analisis yang digunakan yaitu analisis multivariable Structural Equation Modeling (SEM) dengan alat bantu software Partial Least Square (Smart-PLS).

\section{Hasil dan Pembahasan}

Setelah dilakukan tabulasi terhadap 92 kuesioner, maka dapat disajikan distribusi ketekteristik responden berdasarkan usia, jenis kelamin, tingkat pendidikan, pekerjaan, jumlah penghasilan, status pernikahan dan lama menderita DM tipe 2 sebagai subjek penelitian
Tabel 1. Tabel Mean dan Standar Deviasi Responden Berdasarkan Usia dan Lama Menderita DM Tipe 2 di Wilayah Kecamatan Gombong Tahun 2015 ( $\mathrm{n}=92)$

\begin{tabular}{lcc}
\hline \multicolumn{1}{c}{ Karakteristik } & Mean & SD \\
\hline Usia (tahun) & 56,8 & 9,9 \\
Lama Menderita DM tipe & 5,1 & 7,1 \\
2 (tahun) & & \\
\hline
\end{tabular}

Hasil penelitian pada tabel 1 menunjukkan bahwa rata-rata responden berusia 56,8 tahun dengan standar deviasi 9,9 tahun. Rata-rata lama responden menderita DM tipe 2 adalah 5,1 tahun dengan standar deviasi 7,1 tahun. Selanjutnya karakteristik responden menurut jenis kelamin, tingkat pendidikan, pekerjaan, jumlah penghasilan, dan status perkawinan dapat dilihat pada tabel 2 . berikut ini

Tabel 2. Distribusi Frekuensi Responden Berdasarkan, Jenis Kelamin,Tingkat Pendidikan, Pekerjaan, Jumlah penghasilan, dan Status Perkawinan di Wilayah Kecamatan Gombong Tahun 2015 (n=92)

\begin{tabular}{lcc}
\hline \multicolumn{1}{c}{ Karakteristik } & Frekuensi & Persentase (\%) \\
\hline Jenis kelamin & 38 & \\
Laki-laki & 54 & 41,3 \\
Perempuan & & 58,7 \\
Tingkat Pendidikan & 5 & \\
$\quad$ Tidak Sekolah & 52 & 5,4 \\
SD & 9 & 56,5 \\
SMP & 15 & 9,8 \\
SMA & 11 & 16,3 \\
PT & & 12,0 \\
Pekerjaan & 61 & \\
Tidak Bekerja & 23 & 66,3 \\
Petani/Pedagang/Buruh & 8 & 25 \\
PNS/TNI/POLRI & & 8,7 \\
Penghasilan & 55 & \\
$<$ Rp 1.000.000 & 37 & 59,8 \\
$>$ Rp 1.000.000 & & 40,2 \\
Status Pernikahan & 76 & 82,6 \\
Menikah & 2 & 2,2 \\
Tidak Menikah & 14 & 15,2 \\
Duda/janda & & \\
\hline
\end{tabular}


Pada tabel 2 menggambarkan sebagian besar responden berjenis kelamin perempuan $(58,7 \%)$, dengan tingkat pendidikan SD $(56,5 \%)$, tidak bekerja $(66,3 \%)$, berpenghasilan kurang dari Rp.1.000.000 (59,8\%) dan menikah atau masih memiliki pasangan hidup $(82,6 \%)$.

Analisis SEM terhadap data penelitian terdiri dari pengeujian outer model (model pengukuran) dan inner model (model struktural). Outer model merupakan model yang menspsifikasikan hubungan antar variabel konstruk dengan reflektornya atau bisa dikatakan bahwa outer model mendefinisikan bagaimana setiap reflektor menggmabarkan konstruknya.

Berdasarkan tabel 3 diatas dapat diketahui bahwa semua reflektor dari motivasi internal (kebutuhan, keyakinan), motivasi eksternal (harga diri, penghargaan/ reward), maupun semua reflektor dari diabetes self management (diet, aktivitas fisik, pemeriksaan rutin, konsumsi obat, perawatan kaki) yang diblok dengan warna abu-abu memiliki nilai yang cukup tinggi yaitu lebih besar dari 0,5. Hal ini menunjukkan bahwa nilai validitas konvergen setiap reflektor valid dan mampu merefleksikan konstruknya masingmasing dengan baik. Nilai validitas konvergen paling kecil adalah pada reflektor perawatan kaki
$(0,588)$ yang merupakan reflektor dari konstruk diabetes self management dan paling besar adalah pada reflektor kebutuhan dan keyakinan (masing-masing 0,989) yang merupakan reflektor dari konstruk motivasi internal.

Nilai validitas diskriminan dilihat dari korelasi setiap reflektor terhadap konstruknya memiliki nilai yang lebih tinggi dibandingkan korelasi tersebut dengan konstruk lainnya. Contoh nilai loading factor kebutuhan lebih tinggi untuk konstruk motivasi internal dibandingkan dengan konstruk motivasi eksternal dan konstruk diabetes self management. Nilai loading factor harga diri dan penghargaan lebih tinggi untuk konstruk motivasi eksternal $(0,800$ dan 0,925$)$ dibandingkan untuk konstruk motivasi internal $(0,537$ dan 0,604) maupun untuk konstruk diabetes self management $(0,383$ dan 0,606$)$. Begitu pula nilai loading factor diet, aktivitas fisik, pemeriksaan rutin, konsumsi obat, dan perawatan kaki lebih tinggi untuk konstruk diabetes self management $(0,629 ; 0,861 ; 0,744$; 0,745 ; dan 0,588) dibandingkan untuk konstruk motivasi internal $(0,373 ; 0,515 ; 0,442 ; 0,373$; dan 0,448$)$ maupun untuk konstruk motivasi eksternal $(0,523 ; 0,482 ; 0,395 ; 0,361 ;$ dan 0,337$)$

Tabel 3. Nilai Loading Factor dan Cross Loading Setiap Reflektor terhadap Konstruknya Responden DM Tipe 2 di Wilayah Kecamatan Gombong Tahun 2015

\begin{tabular}{lccc}
\hline \multicolumn{1}{c}{ Reflektor } & Motivasi Internal & Motivasi Eksternal & Diabetes Self Management \\
\hline Kebutuhan & 0,989 & 0,667 & 0,598 \\
Keyakinan & 0,989 & 0,638 & 0,597 \\
Harga diri & 0,537 & 0,800 & 0,383 \\
Penghargaan & 0,604 & 0,925 & 0,606 \\
Diet & 0,373 & 0,523 & 0,629 \\
Aktivitas fisik & 0,515 & 0,482 & 0,861 \\
Pemeriksaan rutin & 0,442 & 0,395 & 0,744 \\
Konsumsi obat & 0,373 & 0,361 & 0,745 \\
Perawatan kaki & 0,448 & 0,337 & 0,588 \\
\hline
\end{tabular}

Tabel 4. Tabel Nilai Average Variance Extracted (AVE), Composite Reliability dan Cronbach"s Alpha Responden DM Tipe 2 di Wilayah Kecamatan Gombong Tahun 2015

\begin{tabular}{lccc}
\hline \multicolumn{1}{c}{ Variabel Konstruk } & AVE & Composite Reliability & Cronbach's alpha \\
\hline Motivasi Internal & 0,979 & 0,989 & 0,978 \\
Motivasi Eksternal & 0,749 & 0,856 & 0,679 \\
Diabetes Self Management & 0,518 & 0,841 & 0,760 \\
\hline
\end{tabular}


Dari tabel 4. diketahui bahwa motivasi internal, motivasi eksternal, maupun diabetes self management mempunyai nilai AVE lebih besar dari 0,5 sehingga dapat dikatakan model pengukuran cukup baik. Selain itu diketahui pula composite reliability untuk konstruk motivasi internal, motivasi eksternal maupun Diabetes Self Management semuanya lebih besar dibandingkan 0,8 sehingga dapat dikatakan tiga konstruk mempunyai nilai reliabilitas tinggi. Demikian pula diketahui nilai Cronbach's Alpha semuanya lebih besar dari 0,6 sehingga tiga konstruk yang diteliti tersebut reliabel.

Evaluasi Inner Model penelitian ini dapat dilihat menggunakan nilai koefisien path dan t-statistic. Penilaian terhadap uji didasarkan pada indicator $\mathrm{R}^{2}$ (reliabilitas indicator) yang merupakan uji goodness-fit.

Berdasarkan tabel $5 \mathrm{di}$ atas, diperoleh hasil nilai koefisien jalur struktural motivasi internal terhadap Diebetes Self Management sebesar 0,377 dan nilai koefisien jalur struktural motivasi eksternal terhadap Diebetes Self Management sebesar 0,344. Pada tabel 5 dapat diketahui nilai t-statistik motivasi internal $(3,799)$ lebih besar dibandingkan tabel $(1,96)$ dengan nilai $\mathrm{p}=0,000$, sehingga dapat dinyatakan bahwa motivasi internal mempunyai pengaruh signifikan terhadap diabetes self management. Begitu pula diketahui nilai t-statistik motivasi eksternal $(3,117)$ lebih besar dibandingkan ttabel $(1,96)$ dengan nilai $p=0,002$, sehingga motivasi eksternal juga mempunyai pengaruh signifikan terhadap Diabetes Self Management.

Untuk melihat persentase pengaruh dari setiap variabel laten eksogen terhadap variabel endogen, berikut disajikan koefisien determinan parsial simultan $\left(\mathrm{R}^{2}\right)$ yang merupakan hasil kali dari koefisien dengan variabel laten endogen, dengan nilai $\mathrm{R}^{2}$ adalah 0,431 , artinya bahwa motivasi internal dan eksternal memberikan pengaruh terhadap diabetes self management sebesar 43,1\%, sedangkan sisanya 56,9\% merupakan pengaruh variabel lain yang tidak diteliti. Untuk memvalidasi model secara keseluaruhan dapat dilihat dari nilai Goodness of Fit (GoF) yang didapatkan 0,353 (cenderung moderat) nilai ini mengindikasikan kesesuaian yang baik antara model dengan teori yang digunakan.

Hasil penelitian ini secara tidak langsung mendukung teori Ryan \& Deci (2000) dalam Williams., McGregor., Zeldman, Freedman, \& Deci (2004) salah satu faktor yang mempengaruhi diabetes self management yaitu motivasi. Shigaki et al (2010) motivasi merupakan variabel yang signifikan terhadap self care diabetes, terutama dalam mempertahankan diet dan monitoring gula darah. Seseorang dapat termotivasi oleh tujuan dan harapan yang diinginkan. Menurut Britt (2008), motivasi berkorelasi positif dengan proses berubah, termasuk perubahan gaya hidup. Individu dengan motivasi yang tinggi akan terlihat pada perilakunya. Terbentuknya motivasi pada diri seseorang dalam menjalankan pengelolaan tidak hanya didasarkan tingkat pendidikan, pengalaman pribadi tentang kegagalan, keberhasilan dan lingkungan dalam pengelolaan juga dapat menjadi dasar motivasi penderita untuk melaksanakan perawatan diri yang baik. Motivasi merupakan faktor penting bagi penderita diabetes, karena motivasi yang ada pada diri penderita mampu memberikan dorongan yang kuat untuk melakukan self management diabetes.

Dalam penelitian ini, motivasi internal tergambar oleh reflektor-reflektor yaitu kebutuhan dan keyakinan yang secara valid mampu merefleksikan motivasi internal dengan baik. Hal ini berarti bahwa penderita yang memiliki dasar motivasi dari aspek kebutuhan dan keyakinan yang baik akan mengalami peningkatan yang signifikan dalam self management diabetes. Kusniawati (2011) dalam analisisnya bahwa keyakinan sebagai dimensi dari motivasi internal mempunyai hubungan yang signifikan terhadap efektifitas penatalaksanaan diabetes. Menurut Senecal, dkk (2000), keyakinan diri yang tinggi akan berpengaruh terhadap kepatuhan. Indikator kedua pembentuk motivasi internal yaitu kebutuhan. Kebutuhan harus terpenuhi sebagai faktor pendorong (motif) yang menyebabkan seseorang beraktivitas. Adanya kebutuhan menyebabkan individu beraktivitas dan mempertahankan aktivitas hingga kebutuhannya terpenuhi.

Motivasi eksternal tergambar oleh dimensi penghargaan dan harga diri. Schneider, et al (2009) dalam penelitiannya mengungkapkan bahwa penghargaan yang diberikan kepada penderita DM memiliki efek perlindungan terhadap gangguan emosional seperti putus asa, cemas dan depresi pada penderita penyakit kronik. Berbagai perubahan kesehatan dapat menimbulkan gangguan fisik dan psikologis (Potter \& Perry, 2010). Penyakit kronis dan perubahan fisik yang terjadi menyebabkan perubahan citra tubuh, mengganggu identitas dan harga diri penderita.

Menurut Sofiana, (2012) penderita DM tipe 2 mayoritas memiliki citra tubuh yang negatif. Citra tubuh yang negatif disebabkan oleh manifestasi penyakit DM. DM tipe 2 menyebabkan kehilangan berat badan yang signifikan, terjadinya ulkus diabetikum yang sulit sembuh dan dapat mempengaruhi identitas dan harga diri (Potter \&Perry, 2010). Menurut Kozier (2008) kehilangan bagian tubuh dan fungsi tubuh dapat mempengaruhi harga diri penderita 
diabetessehinggaakanmempengaruhimotivasi dalam melakukan aktivitas pengelolaan penyakit.

Seorang individu yang memiliki motivasi yang tinggi akan memperlihatkan perilaku dan keyakinan yang baik dalam melakukan tugas tertentu. Melihat pentingnya motivasi internal maupun eksternal terhadap pelaksanaan diabetes self management, maka menjadi penting bagi perawat untuk menentukan intervensi dalam meningkatkan motivasi dengan memberikan pengetahuan melalui pendidikan kesehatan dan konseling, motivasi, dukungan, arahan kepada klien dan keluarga agar mempertahankan aktifitas self management dalam kehidupan sehari-hari sehingga kestabilan gula darah dapat tercapai. Perawat melakukan evaluasi terhadap motivasi penderita yang datang dipelayanan kesehatan agar tetap semangat untuk melakukan perilaku self management diabetes.

Adapaun keterbatasan dalam penelitian ini adalah keterbatasan dalam pengukuran perilaku diabetes self management. Aktivitas diabetes self management pada responden dilakukan dengan mengingat aktivitas pengelolaan diabetes yang sudah dilakukan selama satu minggu yang lalu, sehingga ada kemungkinan recall bias saat responden mengisi kuesioner tersebut.

Tabel 5. Nilai Koefisien Jalur Struktural dan Uji Signifikansi Hipotesis (Path Coefficien) Responden DM Tipe 2 di Wilayah Kecamatan Gombong Tahun 2015

\begin{tabular}{lccccc}
\hline & $\begin{array}{c}\text { Original } \\
\text { Sample (O) }\end{array}$ & $\begin{array}{c}\text { Sample } \\
\text { Mean } \\
(\boldsymbol{M})\end{array}$ & $\begin{array}{c}\text { Standard } \\
\text { Error } \\
(\text { STERR) }\end{array}$ & $\begin{array}{c}\text { t Statistics } \\
(\mid \mathbf{O} \text { STERR })\end{array}$ & P values \\
\hline Motivasi Internal ->DSM & 0,377 & 0,381 & 0,099 & 3,799 & 0,000 \\
Motivasi Eksternal ->DSM & 0,344 & 0,348 & 0,110 & 3,117 & 0,002 \\
\hline
\end{tabular}

*) Signifikansi untuk $\alpha=5 \%$ Nilai t tabel $(1,96)$

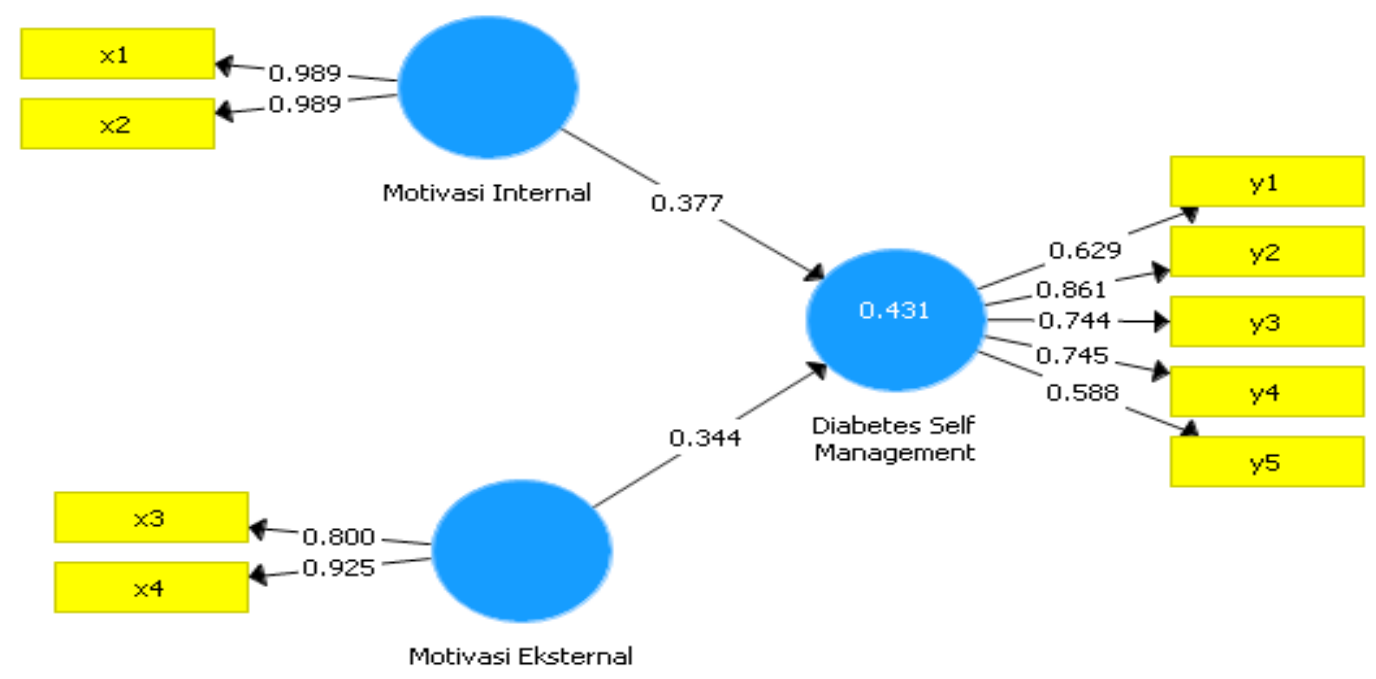

Gambar 1. Nilai Path Coefficient 


\section{Kesimpulan dan Saran}

Berdasarkan hasil penelitian dan pembahasan dapat disimpulkan sebagai berikut : 1. Dimensi kebutuhan dan keyakinan
dapat internal dengan loading factor $(0,989)$.

2. Dimensi penghargaan $(0,925)$ dan harga diri $(0,800)$ dapat menggambarkan motivasi eksternal, dengn dimensi penghargaan paling menggambarkan motivasi eksternal.

3. Dimensi diet, aktivitas fisik, pemeriksaan rutin, konsumsi obat, dan perawatan kaki mampu menggambarkan konstruk diabetes self management.

4. Motivasi internal dan eksternal berpengaruh secara signifikan dan memberikan pengaruh sebesar $43,10 \%$, terhadap diabetes self management pada penderita DM Tipe 2 di wilayah Kecamatan Gombong. Saran teoritis dari penelitian ini adalah dilakukan penelitian lanjutan mengenai $56,9 \%$ faktorfaktor lain yaitu pengetahuan, health belief, self efficacy, dukungan sosial yang dapat mempengaruhi Diabetes Self Management. Adapun saran praktisnya, yang pertama bagi pelayanan keperawatan dapat dijadikan sebagai bahan pengakajian motivasi dalam asuhan keperawatan pada penderita DM Tipe 2 di Puskesmas Kecamatan Gombong Kabupaten Kebumen. Kedua, penting bagi perawat untuk meningkatkan dimensi kebutuhan, keyakinan, penghargaan dan harga diri pada penderita DM tipe 2 oleh perawat, keluarga dan lingkungan dalam pengelolaan diabetes secara mandiri. Bagi pendidikan keperawatan dapat digunakan sebagai bahan masukan kurikulum pembelajaran untuk meningkatkan ketrampilan pengkajian motivasi pada proses asuhan keperawatan dan meningkatkan kemampuan mahasiswa menjadi motivator pada penderita DM tipe 2 dalam pengelolaan penyakitnya.

\section{Daftar Pustaka}

1. Ariani, Y., Sitorus, R., \& Gayatri, D. (2013). Motivasi dan Efikasi Diri Pasien Diabetes Melitus Tipe 2 dalam Asuhan Keperawatan. Jurnal Keperawatan Indonesia, 15(1).

2. Britt, E. Enhancing diabetes self-management: motivational enhancement Therapy (Thesis, Department Of Psychology, University Of Canterbury). 2008. [Online journal] 2008. [Diunduh 24 Desember 2014]. Tersedia dari http://www.proquest.com

3. Gao, Wang, Zhu, Yu. Validation of an information motivation behavioral skills model of self-care among Chinese adults with type 2 diabetes. BMC Public Health. [Online journal] 2013 [diunduh 10 April 2014] Tersedia dari : http://www.biomedcentral.com

4. Kozier, B. (2008). Fundamentals of nursing: concepts, process and practice. Pearson Education.

5. Kose, K., \& Gurkan, T. (2008). The impact of patient education on Diabetes Empowerment Scale (DES) and Diabetes Attitude Scale (DAS-3) in patients with type 2 diabetes. journals.tubitak.gov.tr (diunduh 2 Juni 2014).

6. Kusniawati.Analisisfaktoryang Berkonstribusi Terhadap self care Diabetes Pada Klien Diabetes Mellitus Tipe 2 Di Rumah Sakit Umum Tangerang (Tesis). Depok.FK UI. 2011

7. La Greca, A. M. (2004). Manual for the self care inventory. Miami, FL: University of Miami. [dinduh 12 Agustus 2014]. Tersedia dari : http://www.psy.miami.edu

8. Perkeni. 2011. Pengelolaan Diabetes Melitus. [diunduh 30 April 2014]. Tersedia dari : http:// perkeni.net/old/pengelolaan-diabetes.html

9. Potter, P. A. \& Perry, A. G. 2010. Buku Ajar Fundamental Keperawatan: konsep, proses, dan praktik. Jakarta: EGC.

10. Schneider,S.,Ianotti,R. J.,nansel, T.N., Haynie, D. 1., soble, D. O., \& Morton, B. S. (2009). Assessment of an illness-specific dimension of self-esteem in youths with type 1 diabetes. Journal of Pediatric Psychology , 283-293.

11. Shigaki, C., Kruse, R. L., Mehr, D., Sheldon, K. M., Ge, B., Moore, C., \& Lemaster, J. (2010). Motivation and diabetes self-management. Chronic illness. [diunduh 30 Maret 2014]. Tersedia dari :http//:proquest.com

12. Smeltzer, S. C., \& Bare, B. G. 2010. Buku Ajar Keperawatan Medikal-Bedah Brunner dan Suddarth Volume 2, Edisi 8. Jakarta: EGC.

13. Sofiana, L. I., Elita, V., \& Utomo, W. (2014). Hubungan Antara Stress Dengan Konsep Diri Pada Penderita Diabetes Mellitus Tipe 2. Jurnal Ners Indonesia, 2(2), 167-176.

14. Suyono, S., 2006, Buku Ajar Ilmu Penyakit Dalam, Jilid III, Edisi IV, Hal. 18521856, Diabetes Mellitus di Indonesia; Suyodo, Setiyohadi, Alwi I, Simadibrata, Setiati (eds), Balai Penerbit Fakultas Kedokteran, Universitas Indonesia, Jakarta.

15. Weiler, D.M \& Janice, D.C (2007). Diabetes self management in the migrant Latino population. Hispanic Health Care International. [diunduh 2 Desember 2014] Tersedia dari : ingentaconnect.com

16. WHO. (2012). Fact sheet diabetes. [diunduh 2 Desember 2014]. Tersedia dari: $\quad$ http://www.who.int/medidiacentre 
17. Williams, G. C., McGregor, H. A., Zeldman, A., Freedman, Z. R., \& Deci, E. L. Testing a self-determination theory process model for promoting glycemic control through diabetes self-management. Health Psychology. 2004. [diunduh 2 Desember 2014]. Tersedia dari : http//: psycnet.apa.org 18. Wu, S. F. (2007). Effectiveness of self management for person with type 2 diabetes following the implementation of a selfefficacy enhancing intervention program in Taiwan (Dissertation, Queensland University of Technology). Diunduh dari Proquest Digital Dissertations. [diunduh 10 Desember 2014]. Tersedia dari : http://www.proquest.com 